\title{
Histologic and Clinical Effects of Different Topical Corticosteroids for Eosinophilic Esophagitis: Lessons from an Updated Meta-Analysis of Placebo-Controlled Randomized Trials
}

\author{
Jocelyn de Heer ${ }^{a}$ Stephan Miehlke ${ }^{a, b}$ Thomas Rösch ${ }^{a}$ Andrea Morgner ${ }^{c}$ \\ Yuki Werner $^{\mathrm{a}}$ Hanno Ehlken ${ }^{\mathrm{a}}$ Heiko Becher ${ }^{\mathrm{d}}$ Annette Aigner ${ }^{\mathrm{d}} \mathrm{e}$ \\ aDepartment of Interdisciplinary Endoscopy and Center for Esophageal Disorders, University Hospital \\ Hamburg-Eppendorf, Hamburg, Germany; ${ }^{b}$ Center for Digestive Diseases, Internal Medicine Center \\ Hamburg-Eppendorf, Hamburg, Germany; ' University Cancer Center Hamburg (UCCH), University Hospital

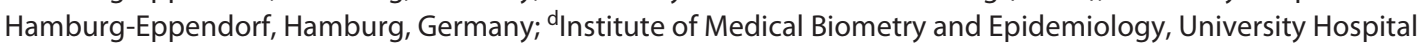

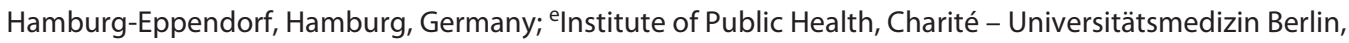 \\ Berlin, Germany
}

\section{Keywords}

Eosinophilic esophagitis · Budesonide · Fluticasone ·

Treatment · Dysphagia

\begin{abstract}
Background: Topical corticosteroids (TS) have become standard therapy for eosinophilic esophagitis (EoE). However, a variety of drug formulations have been used for which results of histological and clinical responses may be different. We aimed at determining the short-term histologic efficacy of TS for EoE based on randomized placebocontrolled trials and to review clinical response. Methods: We searched MEDLINE, ISI Web of Science, and clinicaltrials. gov for randomized controlled trials (RCTs) on TS versus placebo for active EoE published until June 2019. Treatment effects were calculated as risk ratios (RRs) comparing histologic remission between groups. Results: Nine RCTs (6 budesonide and 3 fluticasone) involving a total of 483 par-
\end{abstract}

ticipants were included. A substantial overall effect of TS on acute histologic remission (RR 12.5, 95\% confidence interval 6.0-25.9) was found despite varying definitions of histologic response. Indirect comparisons between drug and formulation types showed a trend for a better histologic efficacy of budesonide (RR 13.5 vs. 10.4 fluticasone) and for the orodispersible tablet (RR 46.2 vs. 11.5 suspension, and 10.4 nebulized formula/spray), but only based on small patient numbers. Scores used for clinical response assessment were different between studies, and short-term clinical results were less impressive: significant differences favoring TS were found in 4/9 RCTs (4/6 budesonide, 0/3 fluticasone). Conclusions: TS are effective for short-term induction of histological remission in EoE with less impressive clinical response rates. The mode of drug delivery to the esophagus may be a relevant factor for the degree of histologic remission. Further trials should use uniform assessment criteria and long-term patient-centered outcomes.

(c) 2020 S. Karger AG, Basel karger@karger.com

www.karger.com/dig

Karger ${ }^{\prime}=$
๑) 2020 S. Karger AG, Basel
Stephan Miehlke

Center for Digestive Diseases, Internal Medicine Center Hamburg-Eppendorf Eppendorfer Landstraße 42 DE-20249 Hamburg (Germany)

miehlke@faz-eppendorf.de 


\section{Introduction}

Eosinophilic esophagitis (EoE) is a chronic, immunemediated disorder of the esophagus which is characterized by an eosinophil-predominant inflammation of the esophagus and clinical signs of esophageal dysfunction $[1,2]$. During the last 2 decades, an increasing incidence of EoE has been described in many European countries and North America and also in other parts of the world [2-5]. Today, EoE is considered the most prevalent cause of chronic esophagitis after gastroesophageal reflux disease and the leading cause of dysphagia and food impaction [3]. EoE can affect all age-groups with a predominance for males, but typically presents in the fourth decade of life. The clinical features may vary by age. In infants and children, EoE may cause feeding problems, vomiting, heartburn, and abdominal pain, while in adolescents and adults, the predominant symptoms are dysphagia for solid foods and bolus obstruction $[6,7]$. In the majority of cases, the natural course of disease appears to be progressive, leading to esophageal remodeling and a high rate of esophageal strictures in the long term $[8,9]$.

Current guidelines recommend topical corticosteroids (TS), elimination diet, and proton pump inhibitors (PPIs) for the treatment for EoE [10]. Several randomized controlled trials (RCTs) have evaluated the efficacy and safety of TS in EoE and previous meta-analyses of these trials confirmed the overall promising results [11-15]. However, considerable differences exist between RCTs with regard to the mode of delivery of the topical steroid to the esophagus, which may be of clinical relevance.

In addition, more recent studies have been conducted using budesonide formulations specifically designed for esophageal administration in EoE, which may have an advantage over topical steroids originally designed for the treatment of asthma. Hence, the aim of this study was to perform a systematic literature review of placebo-controlled randomized trials to determine the efficacy of topical steroids in inducing histological remission in EoE and to evaluate potential factors that might influence treatment efficacy with regard to both histologic as well as clinical response.

\section{Methods}

A literature search was performed in MEDLINE, ISI Web of Science, and clinicaltrials.gov from inception until June 2019. Search terms included "eosinophilic esophagitis," "topical corticosteroid,"

Fig. 1. Flowchart of included and excluded

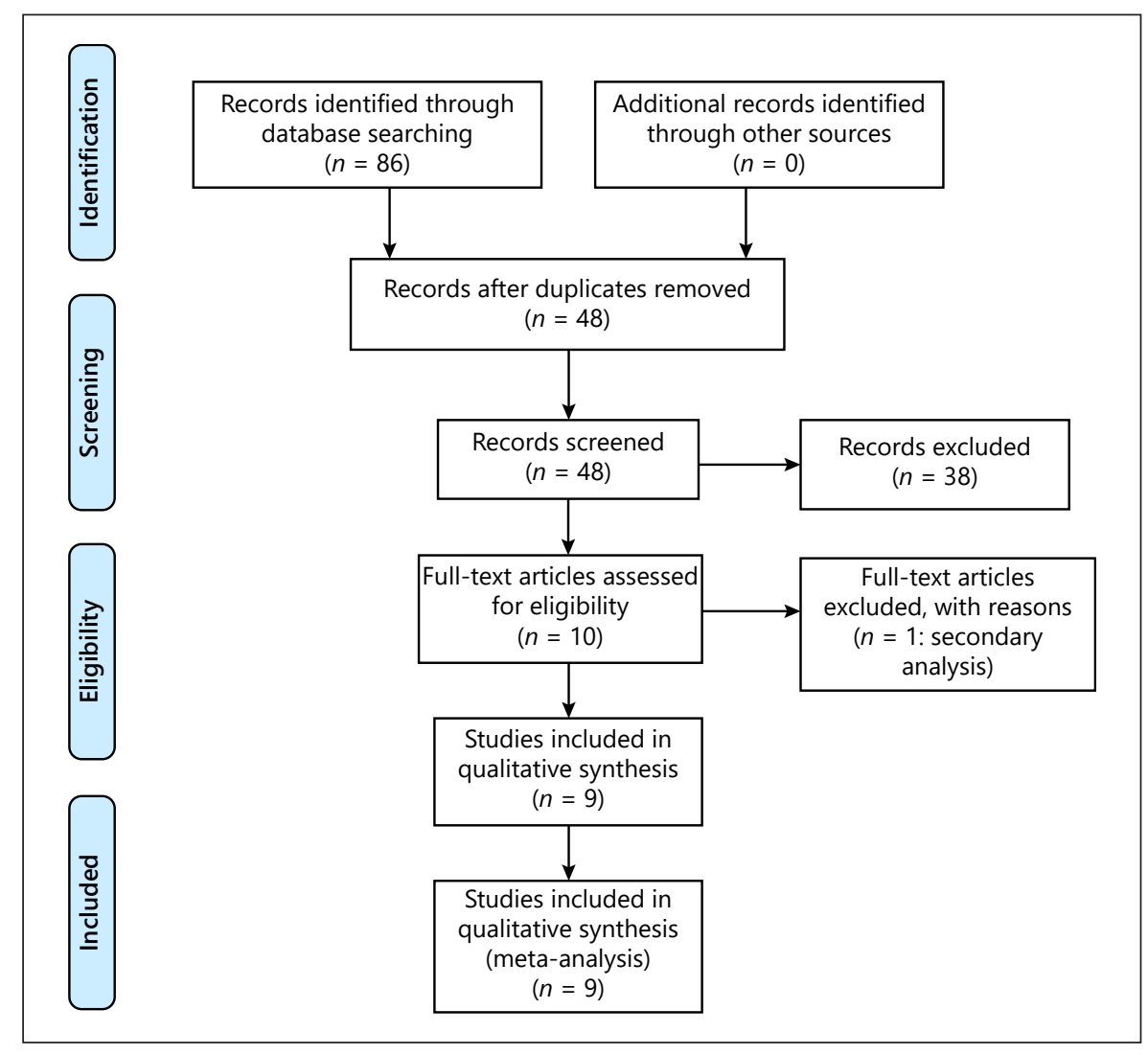
articles in the meta-analysis. 
"fluticasone," "budesonide," "randomized controlled trial," "randomized clinical trial," "trial," and "placebo." The search was restricted to human studies and studies published in English language. Three reviewers (S.M., A.A., and J.d.H.) screened abstracts from database searches according to inclusion and exclusion criteria. The selected studies were reviewed and relevant data extracted. Systematic reviews and meta-analyses published on the same topic were examined for further references. We followed the PRISMA statement [16].

\section{Inclusion and Exclusion Criteria}

We included RCTs comparing the topical steroids budesonide and fluticasone with placebo for treatment of EoE in adults and children. We excluded work without original data, such as secondary analyses of data and meta-analyses. Furthermore, we excluded studies evaluating other types of treatment, such as dietary interventions, and studies without a placebo-controlled arm.

\section{Analysis}

For each study, we calculated risk ratios (RRs), the pooled estimate, and 95\% confidence intervals (CIs). RRs were reported as their interpretation was previously shown to be less error prone and misleading than odds ratios [17]. In the original publications, other effect measures and other statistical tests were used. Statistical heterogeneity was assessed with the Q-Cochrane statistic, quantified by $I^{2}$. We used random effects models with inverse-variance weights, based on restricted maximum likelihood estimation. The value $1 / 2$ is added to each cell of those $2 \times 2$ tables with at least 1 cell equal to 0 [18]. Calculations were based on data and analyses as reported in the respective original publications. Accordingly, one case with missing distal histology was classified as responder as by Konikoff et al. [19], although histologic remission was defined by a peak eosinophil count of $\leq 1$ eos in all high-power fields in both the proximal and distal esophagus.

To explore heterogeneity in study results, we conducted metaanalyses stratified by topical steroid, mode of delivery, patient cohort, and study duration. As one study included 2 modes of delivery, in this subgroup analysis, the respective study was counted as 2 , using the same control group [20]. Results of each meta-analysis were displayed graphically using forest plots. Publication bias was assessed visually with funnel plots. For all analyses, the statistical software $R^{12}$ was used, and meta-analyses were based on the metafor package [21].

Table 1. Main characteristics of studies included in the analysis (9 studies, 483 patients): patients, drugs, and histologic outcomes

\begin{tabular}{|c|c|c|c|c|c|c|c|c|c|}
\hline Authors & $\begin{array}{l}\text { Study } \\
\text { population }\end{array}$ & $\begin{array}{l}\text { Patients }(n) \\
\text { randomized, } \\
\text { analyzed } \\
\text { (active/placebo) }\end{array}$ & Drug & Dosage & $\begin{array}{l}\text { Mode of } \\
\text { delivery }\end{array}$ & $\begin{array}{l}\text { Additional } \\
\text { PPI } \\
\text { (active vs. } \\
\text { placebo) }^{\mathrm{a}}\end{array}$ & $\begin{array}{l}\text { Therapy } \\
\text { duration }\end{array}$ & $\begin{array}{l}\text { Primary } \\
\text { histological } \\
\text { end point }\end{array}$ & $\begin{array}{l}\text { Histologic } \\
\text { remission }\end{array}$ \\
\hline $\begin{array}{l}\text { Konikoff } \\
\text { et al. [19] }\end{array}$ & Children & $\begin{array}{l}36(21 / 15)^{\#} \\
31(20 / 11)^{\#}\end{array}$ & Fluticasone & $440 \mu \mathrm{g}$ BID & $\begin{array}{l}\text { Nebulized/ } \\
\text { swallowed }\end{array}$ & 38 vs. $33 \%$ & 12 weeks & $\leq 1$ eos/all HPF & 50 vs. $9 \% *$ \\
\hline $\begin{array}{l}\text { Straumann } \\
\text { et al. [27] }\end{array}$ & Adults & $\begin{array}{l}36(18 / 18) \\
36(18 / 18)\end{array}$ & Budesonide & $1 \mathrm{mg}$ BID & $\begin{array}{l}\text { Viscous } \\
\text { suspension }\end{array}$ & 72 vs. $56 \%$ & 15 days & $<5$ eos/all $\mathrm{HPF}^{\mathrm{b}}$ & 72 vs. $11 \% *$ \\
\hline $\begin{array}{l}\text { Dohil } \\
\text { et al. [25] }\end{array}$ & Children & $\begin{array}{l}31(\mathrm{c} / \mathrm{c}) \\
24(15 / 9)\end{array}$ & Budesonide & 1-2 mg BID & $\begin{array}{l}\text { Viscous } \\
\text { suspension }\end{array}$ & $\begin{array}{l}\text { Lansoprazole } \\
2 \times 15-30 \mathrm{mg}\end{array}$ & 12 weeks & $\leq 6$ eos/all HPF & 87 vs. $0 \% *$ \\
\hline $\begin{array}{l}\text { Alexander } \\
\text { et al. [22] }\end{array}$ & Adults & $\begin{array}{l}42(21 / 21) \\
34(19 / 15)\end{array}$ & Fluticasone & $880 \mu \mathrm{g}$ BID & $\begin{array}{l}\text { Nebulized/ } \\
\text { swallowed }\end{array}$ & 26 vs. $0 \%^{\mathrm{d}}$ & 6 weeks & $\begin{array}{l}>90 \% \text { reduction } \\
\text { in eos count }\end{array}$ & 68 vs. $0 \% *$ \\
\hline $\begin{array}{l}\text { Butz } \\
\text { et al. [23] }\end{array}$ & $\begin{array}{l}\text { Children } \\
\text { and adults }\end{array}$ & $\begin{array}{l}42(28 / 14) \\
36(23 / 13)\end{array}$ & Fluticasone & $880 \mu \mathrm{g}$ BID & $\begin{array}{l}\text { Nebulized/ } \\
\text { swallowed }\end{array}$ & 71 vs. $71 \%$ & 12 weeks & $\leq 1$ eos/HPF & 65 vs. $0 \% *$ \\
\hline $\begin{array}{l}\text { Miehlke } \\
\text { et al. [20] }\end{array}$ & Adults & $\begin{array}{l}77(58 / 19) \\
76(57 / 19)^{\mathrm{e}}\end{array}$ & Budesonide & $1-2 \mathrm{mg} \mathrm{BID}{ }^{\mathrm{e}}$ & $\begin{array}{l}\text { Orodispersible } \\
\text { tablet, viscous } \\
\text { suspension }^{\mathrm{e}}\end{array}$ & $5-16$ vs. $16 \%$ & 2 weeks & $<5$ eos/HPF & $\begin{array}{l}95-100 \\
\text { vs. } 0 \% *\end{array}$ \\
\hline $\begin{array}{l}\text { Gupta } \\
\text { et al. [26] }\end{array}$ & Children & $\begin{array}{l}81(60 / 21) \\
71(53 / 18)\end{array}$ & Budesonide & $\begin{array}{l}0.35 \mathrm{OD}-2 \mathrm{mg} \\
\text { BIDg }^{\mathrm{f}}\end{array}$ & $\begin{array}{l}\text { Viscous } \\
\text { suspension }\end{array}$ & $\begin{array}{l}41 / 42 / 47 \\
\text { vs. } 17 \%^{\mathrm{f}}\end{array}$ & 12 weeks & $\leq 6 \operatorname{eos} / \mathrm{HPFg}$ & $\begin{array}{l}94^{*} / 53^{*} / \\
24 \text { vs. } 6 \%{ }^{\mathrm{f}}\end{array}$ \\
\hline $\begin{array}{l}\text { Dellon } \\
\text { et al. [24] }\end{array}$ & $\begin{array}{l}\text { Children } \\
\text { and adults }\end{array}$ & $\begin{array}{l}93(51 / 42) \\
87(49 / 38)\end{array}$ & Budesonide & $2 \mathrm{mg}$ BID & $\begin{array}{l}\text { Viscous } \\
\text { suspension }\end{array}$ & 71 vs. $67 \%$ & 12 weeks & $\leq 6$ eos/HPF & 39 vs. $3 \% *$ \\
\hline $\begin{array}{l}\text { Lucendo } \\
\text { et al. [28] }\end{array}$ & Adults & $\begin{array}{l}88(59 / 29), \\
88(59 / 29)\end{array}$ & Budesonide & $1 \mathrm{mg}$ BID & $\begin{array}{l}\text { Orodispersible } \\
\text { tablet }\end{array}$ & 12 vs. $10 \%^{*}$ & 6 weeks & $<5$ eos/HPF ${ }^{\mathrm{h}}$ & 93 vs. $0 \% *$ \\
\hline
\end{tabular}

PPI, proton pump inhibitor; OD, once daily; BID, twice daily; HPF, high-power field; EoE, eosinophilic esophagitis. * $p<0.05 .{ }^{*}$ One case with missing distal histology was classified by Konikoff et al. [19] as responder, although histologic remission was defined as $\leq 1$ eos/all HPF, in both proximal and distal

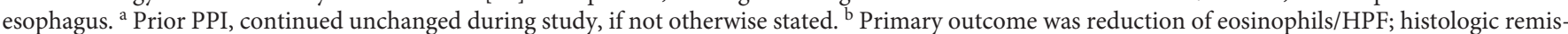
sion $\left(\leq 5\right.$ eos/all HPF) was an additional outcome. ${ }^{c}$ Exact number of patients allocated to active/placebo group not specified. ${ }^{\mathrm{d}}$ Prestudy 52 versus $57 \%$, during study 26 versus $0 \% .{ }^{e}$ Budesonide was given in 3 groups, orodispersible tablet $2 \times 1$ or $2 \times 2 \mathrm{mg}$, viscous suspension $2 \times 2$ mg. ${ }^{\mathrm{f}}$ Subjects were randomized to low-, medium-, and high-dose stratified by age older/younger than 9 years or placebo. ${ }^{\mathrm{g}}$ The study had a primary composite outcome, namely histologic response as mentioned plus 50\% reduction in an unvalidated EoE symptom score. ${ }^{\mathrm{h}}$ The study had a primary composite outcome requiring nearly complete clinicohistologic remission, namely histologic response as mentioned plus relief of dysphagia and odynophagia with no or only minimal clinical symptoms.

Topical Corticosteroids in Eosinophilic Esophagitis 
Table 2. Main characteristics of studies included in the analysis ( 9 studies, 483 patients): patients and clinical outcomes

\begin{tabular}{|c|c|c|c|c|c|c|c|}
\hline Authors & $\begin{array}{l}\text { Patients }(n) \\
\text { analyzed } \\
\text { (active/ } \\
\text { placebo) }\end{array}$ & Drug & $\begin{array}{l}\text { Therapy } \\
\text { duration }\end{array}$ & $\begin{array}{l}\text { Histologic } \\
\text { remission } \\
\text { (definition } \\
\text { see Table 1) }\end{array}$ & $\begin{array}{l}\text { Clinical score used (dysphagia } \\
\text { or combined symptoms) }\end{array}$ & $\begin{array}{l}\text { Clinical effect; pre- vs. } \\
\text { post-treatment }\end{array}$ & $\begin{array}{l}\text { Clinical effect; } \\
\text { treatment vs. } \\
\text { placebo }\end{array}$ \\
\hline $\begin{array}{l}\text { Konikoff } \\
\text { et al. [19] }\end{array}$ & $31(20 / 11)^{\#}$ & Fluticasone & 12 weeks & 50 vs. $9 \% *$ & $\begin{array}{l}11 \text { symptoms recorded (no } \\
\text { details), in } 67 \% \text { retrospectively }\end{array}$ & $\begin{array}{l}\text { Improvement versus baseline } \\
\text { for vomiting only* }\end{array}$ & Not reported \\
\hline $\begin{array}{l}\text { Straumann } \\
\text { et al. [27] }\end{array}$ & $36(18 / 18)$ & Budesonide & 15 days & 72 vs. $11 \% *$ & $\begin{array}{l}\text { Non-validated dysphagia score } \\
\text { (range 0-9) same as [20] }\end{array}$ & $\begin{array}{l}\text { Score decrease by } 60 \% \text {, (from } \\
5.61 \text { to } 2.22)^{*}\end{array}$ & $\begin{array}{l}\text { Score decrease } \\
\text { by } 60 \text { vs. } 11 \%^{*}\end{array}$ \\
\hline $\begin{array}{l}\text { Dohil } \\
\text { et al. [25] }\end{array}$ & $24(15 / 9)$ & Budesonide & 12 weeks & 87 vs. $0 \% *$ & $\begin{array}{l}\text { Non-validated symptom } \\
\text { scoring tool (range } 0-14 \text { ) }\end{array}$ & $\begin{array}{l}\text { Score decrease by } 66 \% \text { (from } \\
3.5 \text { to } 1.2)^{*}\end{array}$ & $\begin{array}{l}\text { Score decrease } \\
\text { by } 66 \text { vs. } 33 \%^{*}\end{array}$ \\
\hline $\begin{array}{l}\text { Alexander } \\
\text { et al. [22] }\end{array}$ & $34(19 / 15)$ & Fluticasone & 6 weeks & 68 vs. $0 \% *$ & $\begin{array}{l}\text { Mayo dysphagia questionnaire } \\
\text { (3 grades) }\end{array}$ & Not reported & $\begin{array}{l}\text { Complete } \\
\text { response } 47 \\
\text { vs. } 40 \%-\text { ns }\end{array}$ \\
\hline $\begin{array}{l}\text { Butz } \\
\text { et al. [23] }\end{array}$ & $36(23 / 13)$ & Fluticasone & 12 weeks & 65 vs. $0 \% *$ & $\begin{array}{l}\text { Semi-validated EoE symptom } \\
\text { score (pediatric) }\end{array}$ & Not reported & ns \\
\hline $\begin{array}{l}\text { Miehlke } \\
\text { et al. [20] }\end{array}$ & $76(57 / 19)$ & Budesonide & 2 weeks & $\begin{array}{l}95-100 \\
\text { vs. } \%^{\mathrm{a}, *}\end{array}$ & $\begin{array}{l}\text { Non-validated dysphagia score } \\
\text { (range 0-9) same as [27] }\end{array}$ & $\begin{array}{l}\text { Score decrease in all groups }{ }^{\mathrm{a}} \text {, } \\
\text { also placebo* }\end{array}$ & ns \\
\hline $\begin{array}{l}\text { Gupta } \\
\text { et al. [26] }\end{array}$ & $71(53 / 18)$ & Budesonide & 12 weeks & $\begin{array}{l}94^{*} / 53^{* /} \\
24 \text { vs. } 6 \%{ }^{\mathrm{b}}\end{array}$ & $\begin{array}{l}\text { New unvalidated EoE symptom } \\
\text { score (EoE CSS: range } 0-18 \text { ) }\end{array}$ & $\begin{array}{l}\text { Response rates }(\geq 50 \% \\
\text { reduction in EoE CSS), } \\
53 / 79 / 65 \text { vs. } 78 \%^{\text {b }} \text {, no } p \text { value } \\
\text { reported }\end{array}$ & ns \\
\hline $\begin{array}{l}\text { Dellon } \\
\text { et al. [24] }\end{array}$ & $87(49 / 38)$ & Budesonide & 12 weeks & 39 vs. $3 \% *$ & $\begin{array}{l}\text { DSQ score (Prevalidated } \\
\text { dysphagia diary) }\end{array}$ & $\begin{array}{l}\text { Decrease in DSQ score by } 49 \% \text {, } \\
\text { from } 29.3 \text { to } 15 \text {, no } p \text { value } \\
\text { reported }\end{array}$ & $\begin{array}{l}\text { Decrease by } \\
49 \text { vs. } 26 \% *\end{array}$ \\
\hline $\begin{array}{l}\text { Lucendo } \\
\text { et al. [28] }\end{array}$ & $88(59 / 29)$ & Budesonide & 6 weeks & 93 vs. $0 \% *$ & $\begin{array}{l}\text { Dysphagia and odynophagia } \\
\text { based on NRS from } 0 \text { to } 10\end{array}$ & No $p$ value reported & $\begin{array}{l}\leq 2 \text { on each NRS } \\
59 \text { vs. } 14 \% *\end{array}$ \\
\hline
\end{tabular}

EoE, eosinophilic esophagitis; DSQ, Dysphagia Symptom Questionnaire; NRS, numerical rating scale; HPF, high-power field; ns, not significant. * $p<$ 0.05. " One case with missing distal histology was classified by Konikoff et al. [19] as responder, although histologic remission was defined as $\leq 1$ eos/all HPF, in both proximal and distal esophagus. ${ }^{a}$ Budesonide was given in 3 groups, orodispersible tablet $2 \times 1 \mathrm{mg}$ or $2 \times 2 \mathrm{mg}$, viscous suspension $2 \times 2 \mathrm{mg}$. ${ }^{\mathrm{b}}$ Subjects were randomized to low-, medium-, and high-dose stratified by age older/younger than 9 years or placebo.

\section{Results}

\section{Study Selection and Characteristics}

The search strategy resulted in 86 references, of which after removal of duplicates, 48 were screened (see flowchart in Fig. 1). Of those, 38 were excluded as they did not fulfill our inclusion criteria (e.g., meta-regression, secondary analysis or meta-analysis of data, review, and lack of a placebo-controlled arm). The remaining 9 RCTs based on a total of 483 patients were included for analyses. The major characteristics of the included trials are summarized in Tables 1 and 2. In 3 studies, fluticasone was used and delivered as swallowed spray $[19,22,23]$, whereas in 6 studies, budesonide was administered either as suspension [24-27] or orodispersible tablet [20, 28]. Further differences among studies included the duration of treatment (from 2 to 12 weeks), the dosages of topical steroids, and the study populations ( 3 with pediatric pa- tients, 4 with adult patients, and 2 with pediatric and adult patients). As for PPI pretreatment and/or continuation of PPI therapy, different regimens were followed in various studies (Table 1).

\section{Histologic Remission}

All 9 studies reported histologic remission either as the main outcome or as part of a compound clinicohistologic outcome, which we also used as the outcome of our analyses. However, histologic response was defined differently in the relevant studies, as shown in Table 1. All studies found an advantage of the treatment with topical steroid compared to the placebo (Fig. 2; Table 1). All 9 included studies originally reported a significant histologic remission for the treatment group. The metaanalysis of all 9 studies yielded a large and significant effect estimate RR of 12.5 (95\% CI: 6.0-25.9) with no sign of relevant heterogeneity $\left(I^{2}=0.0 \%, p=0.88\right)$. The 


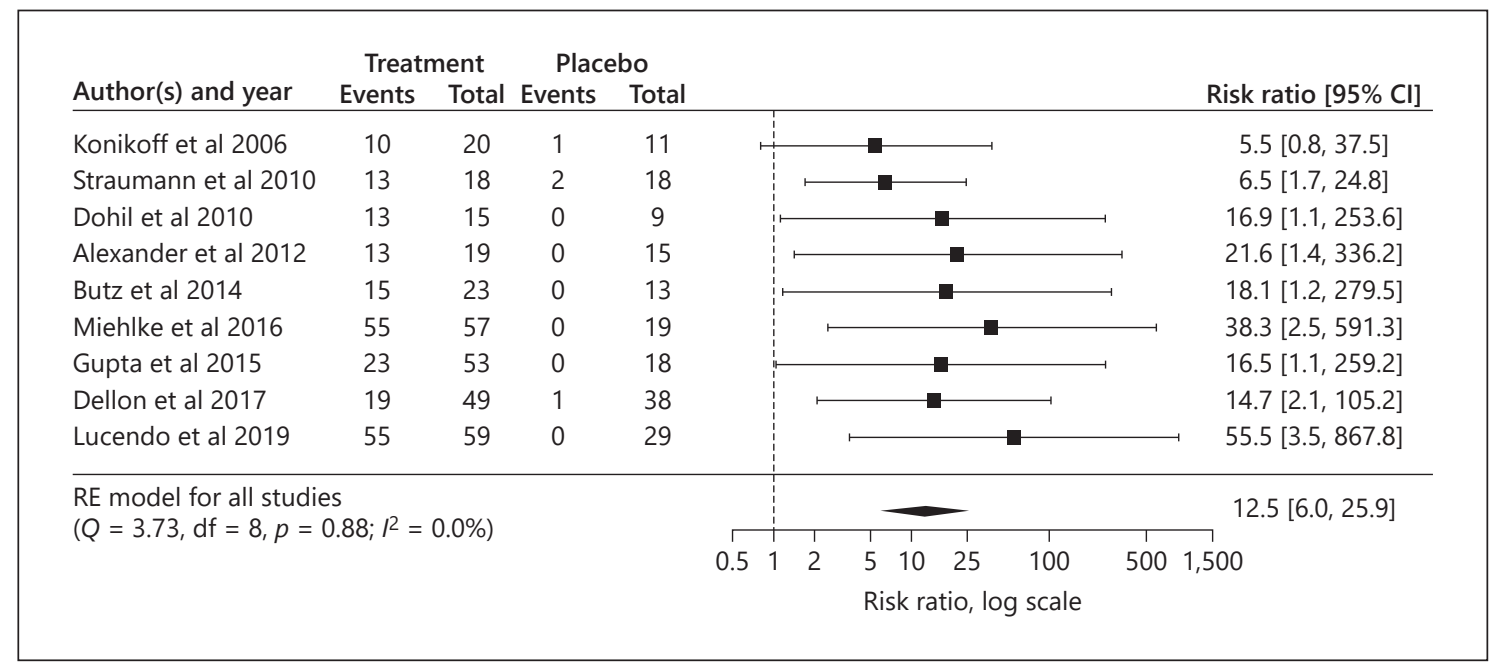

Fig. 2. Forest plot of meta-analysis results of all included placebo-controlled RCTs on topical steroids for treatment of EoE. The box in each row represents the RR for histologic remission in each study, whereas the bar represents the respective 95\% CI. RCT, randomized controlled trial; EoE, eosinophilic esophagitis; RR, risk ratio; CI, confidence interval; RE, random effects.

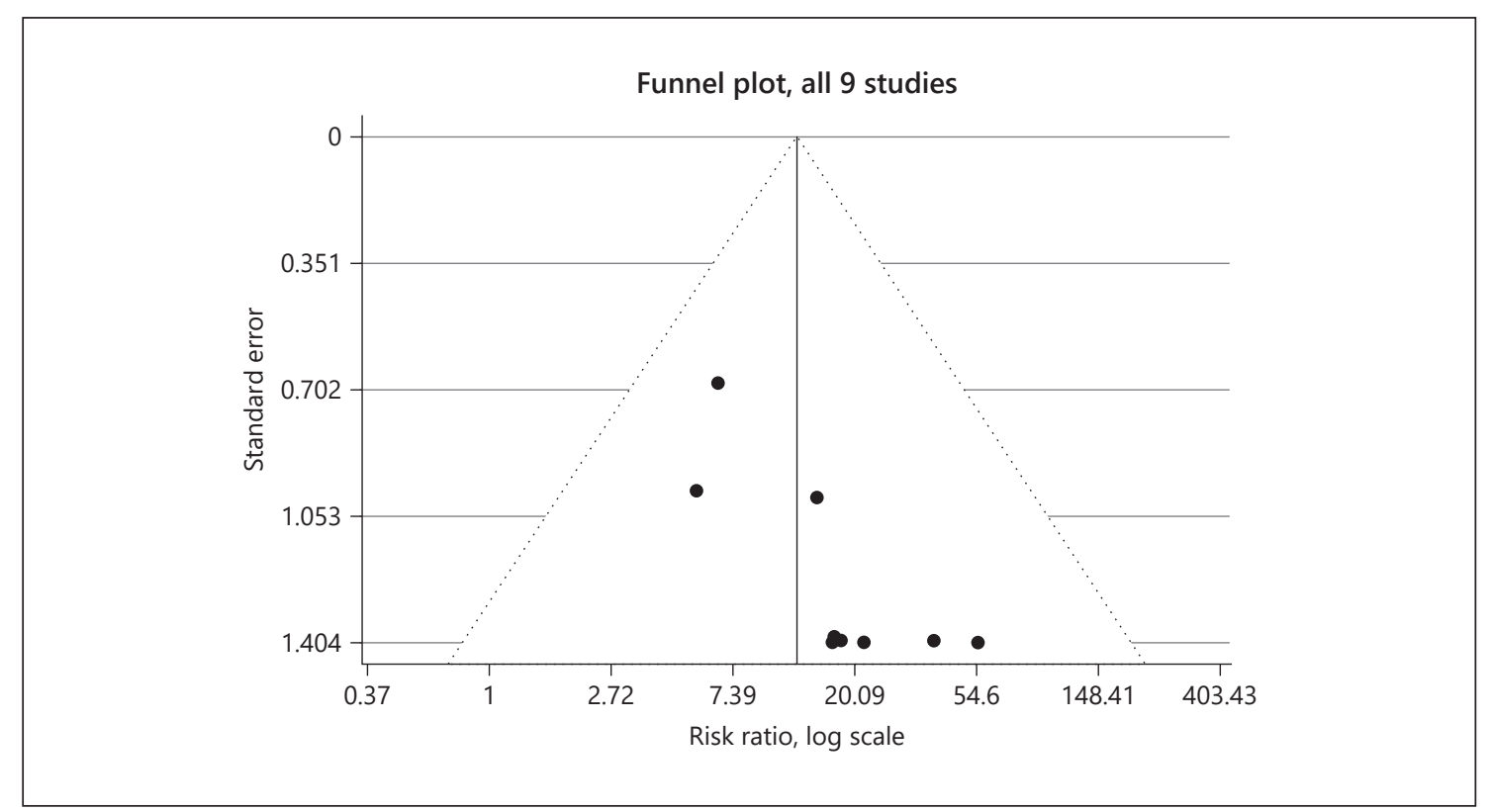

Fig. 3. Funnel plot (see text for details).

funnel plot indicated a potential publication bias (Fig. 3), although the assessment based on only 9 studies is limited.

\section{Subgroup Analyses for Histologic Remission}

The RR estimate for budesonide of 13.5 (95\% CI: 5.731.8) was higher than that for fluticasone (RR 10.4; CI:
2.6-40.5). However, the overlapping CIs indicated that none of the 2 TS was significantly superior to the other (Fig. 4). In an indirect comparison between studies, there was only a trend toward better results with administration of an orodispersible tablet (RR 46.2; 95\% CI: 6.6321.3) than the suspension (RR 11.5; CI: 4.7-28.5) or nebulized formulation/spray (RR 10.4; CI: 2.6-40.5) 


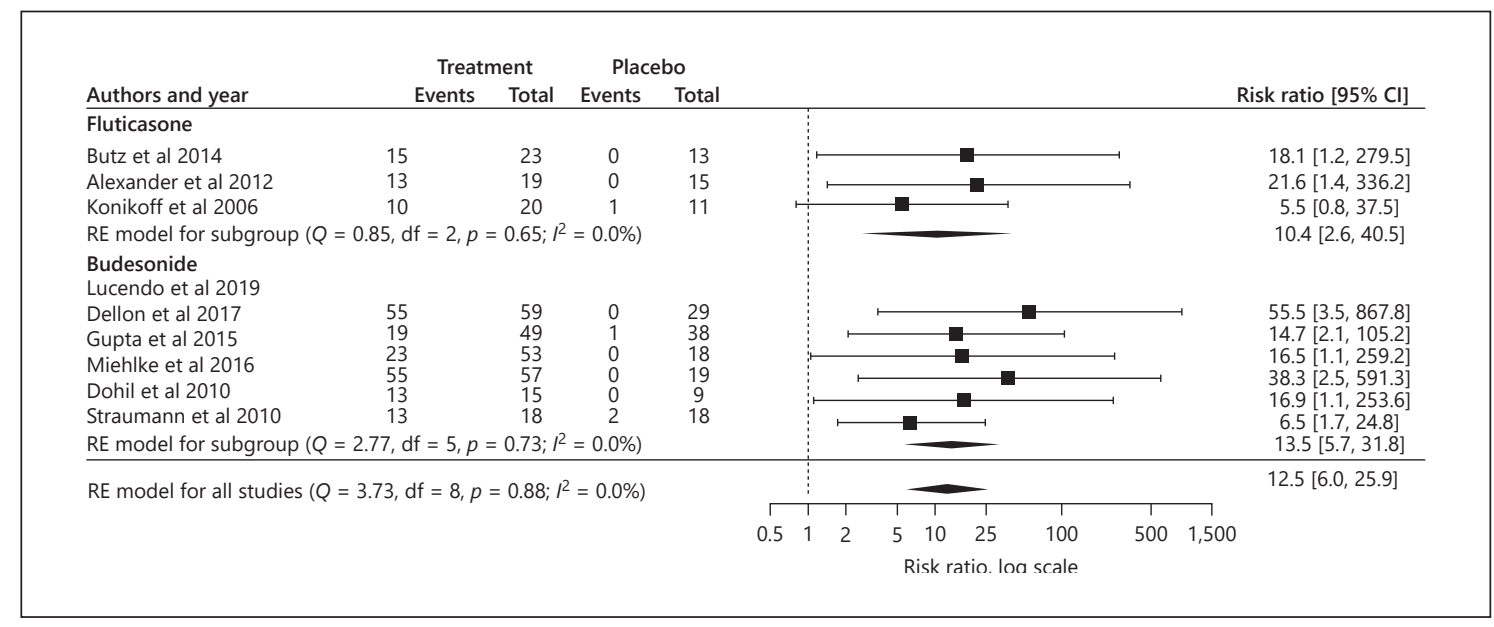

Fig. 4. By topical steroid - forest plot of meta-analysis results of RCTs on topical steroids for treatment of EoE. The box in each row represents the RR for histologic remission in each study, whereas the bar represents the respective 95\% CI. RCT, randomized controlled trial; EoE, eosinophilic esophagitis; RR, risk ratio; CI, confidence interval; RE, random effects.

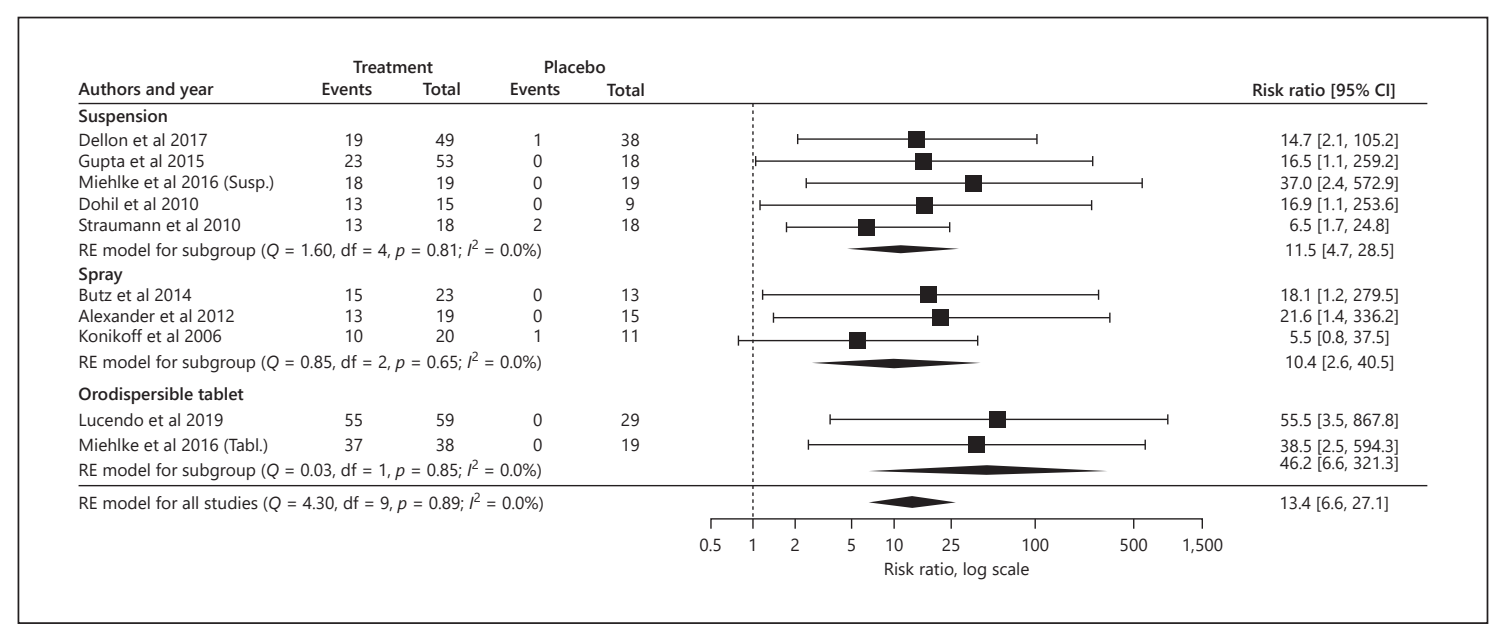

Fig. 5. By mode of delivery - forest plot of meta-analysis results of RCTs on topical steroids for treatment of EoE. The box in each row represents the RR for histologic remission in each study, whereas the bar represents the respective 95\% CI. RCT, randomized controlled trial; EoE, eosinophilic esophagitis; RR, risk ratio; CI, confidence interval; RE, random effects.

(Fig. 5). Regarding study populations, the RR estimate for histologic remission was slightly higher in adults (RR 15.4; CI 4.6-51.6) than in children (RR 9.6; CI 2.4-37.3) (online suppl. Fig. 1; for all online suppl. material, see www.karger.com/doi/10.1159/000507571). In contrast, the duration of treatment did not seem to impact histologic remission, as the results for 2 (RR 10.4; CI 2.2-48.0), 6 (RR 34.6; CI 5.0-241.4), and 12 weeks (RR 11.8; CI 4.2-33.3) of treatment were largely similar (online suppl. Fig. 2).

\section{Clinical Response}

As can be seen from Table 2, with 2 exceptions [20, 27], all studies used different symptom scores, mostly, but not always focusing on dysphagia. This may have to do with the different spectrum of symptomatology between children and adults. Nevertheless, comparability between studies with regard to clinical symptoms is limited, and the magnitude of response, if any, cannot be compared. Thus, a combined analysis of clinical data does not seem to be useful. A descriptive analysis showed, 
however, that none of the 3 RCTs using fluticasone had a significant effect on clinical symptomatology $[19,22$, 23], perhaps partially due to the fact that these studies were all underpowered for this outcome. In contrast, although mostly used as a secondary parameter, a significant clinical response, that is, a significant difference between treatment and placebo group was seen in 4/6 studies using budesonide; however, varying scores (with only one being prevalidated) were applied. Moreover, the clinical scores and effects described were vastly different (differences between drug and placebo in defined response rates vs. symptom improvement, significant differences between drug pre- and post-therapy in contrast to placebo, etc.) with 2 studies even reporting a large symptom response to placebo (Gupta et al. [26], Miehlke et al. [20]). Budesonide showed some clinical effects as viscous suspension in $3 / 4$ studies and as orodispersible tablet in 1/2 studies (Tables 1,2 ).

\section{Discussion}

The current updated review covers all available randomized placebo-controlled trials using topical steroids for the treatment of EoE, and the common denominator of all studies as well as of this analysis is histologic remission. Even though histologic remission was defined differently in most studies, with (slightly) different cutoffs being applied for the number of eosinophils for the definition of remission, all original studies reported significant effects, and thus, we confirmed prior meta-analyses in this respect [11-15]. The histologic response, however, was not accompanied by a uniform and convincing clinical remission in all cases, probably due to various factors: clinical response definition was even more variable, and only 2 RCTs used the same dysphagia score [20, 27]. The combined assessment of children and adults with EoE further obscures the clinical response assessment since the clinical spectrum varies between children and adults $[6,7,9]$.

In addition, and most importantly, the clinical response is likely to take longer than the histologic remission, also depending on the status and course of the disease such as presence of chronic fibrous changes in the esophagus, need for endoscopic dilatation, etc. In the study by Lucendo et al. [28], patients not achieving both clinical and histologic remission after 6 weeks and all patients from the placebo group were offered additional 6 weeks of budesonide treatment. The cumulative rate of patients with clinicohistologic remission rose from $58 \%$

Topical Corticosteroids in Eosinophilic Esophagitis after 6 to $85 \%$ after 12 weeks in the treatment group and from 0 to $79 \%$ in the placebo group.

Thus, although also slightly different with regard to the definition of response, histologic success rates can be pooled in meta-analyses, while clinical response cannot. This did not prevent prior meta-analyses to pool these data as well $[14,29]$.

We also tried to elucidate differences between different drugs and formulations, but limited patient numbers, no direct comparisons, and, therefore, very wide ranges of the confidence intervals preclude firm conclusions. Trends should be considered with great care if they fail to reach statistical significance. For example, based on our analysis on histologic response, budesonide showed a higher effect (compared to placebo) than fluticasone and also with regard to clinical response, only studies with budesonide reached positive results. However, in a recent direct comparative randomized trial on 111 EoE patients, there was no difference between both in terms of histologic and clinical response [30], even if in both groups, the spray formula was used. Thus, evidence from randomized trials may give the final answer also to the superiority of the recently developed gel.

Nevertheless, clinical assessment should be part of further studies and use uniform assessment criteria - this is a strong plea for a consensus-based EoE symptom score for both children and adults - and it should follow up patients for long term. Only three of the randomized trials included in this meta-analysis reported a follow-up period after the end of study treatment, ranging from 2-6 weeks [20,28] up to 3 months [23] (see Table 2). Miehlke et al. [20] described a sustained improvement of dysphagia 2 weeks after the end of treatment, but only in those who had been treated with budesonide $2 \times 1 \mathrm{mg}$, whereas the effects of budesonide $2 \times 2 \mathrm{mg}$ irrespective of mode of delivery did not persist. In the study by Butz et al. [23], fluticasone treatment was continued in complete responders with half dose for additional 3 months, whereas nonresponders of both treatment and placebo group received full dose. Interestingly, $73 \%$ of the responders remained in complete remission (CR), despite the dose reduction. In addition, $62 \%$ of the placebo group achieved $\mathrm{CR}$ after crossover to fluticasone, whereas initial fluticasone nonresponders remained resistant.

A recent large retrospective analysis on 229 patients treated long term with topical steroids and undergoing a median follow-up of 5 years showed better results clinically, endoscopically, and histologically, when topical steroids were still taken, for example, clinical response 31 versus $4.5 \%$; $\mathrm{CR}$, however, was achieved in only $16 \%$ of 
the treated patients (vs. 1\% untreated) [31]. In contrast, the natural course of the disease is determined progression from inflammation toward fibrotic strictures, namely, from 19 to $52 \%$, when the diagnosis was delayed by $\leq 2$ versus $\geq 21$ years [9]. Very recently, results of the maintenance trial were presented with 204 patients treated with either budesonide orodispersible tablet 1 or $2 \mathrm{mg}$ daily versus placebo: in a combined end point of clinical and histologic parameters, 73.5 and $75.0 \%$ versus $4.4 \%$ with placebo were in remission at 48 weeks, and $11-16 \%$ showed symptomatic candidiasis [32].

Thus, in summary, our analysis confirms previous results of topical steroids being very effective in achieving histologic remission in EoE patients, with a lower number of patients showing clinical response. The wide variability in used scores for clinical evaluation is remarkable and should be avoided in future trials. The exact choice of the drug and formulation requires further study, as do the long-term effects of treatment.

\section{Statement of Ethics}

The authors have no ethical conflicts to disclose.

\section{Disclosure Statement}

This analysis was supported by Dr. Falk Pharma, Freiburg, Germany. Otherwise, the authors declare no conflicts of interest.

\section{Funding Sources}

This analysis was supported by Dr. Falk Pharma, Freiburg, Germany.

\section{Author Contributions}

Study selection, data collection, and study data analysis was done by J.d.H., S.M., A.M., and A.A.; meta-analysis by H.B. and A.A.; and manuscript writing by J.d.H., S.M., and T.R., with input and corrections by Y.W., H.E. and all other coauthors. The manuscript was read and approved by all coauthors.

\section{References}

1 Furuta GT, Katzka DA. Eosinophilic esophagitis. N Engl J Med. 2015;373(17):1640-8.

2 Arias Á, Pérez-Martínez I, Tenías JM, Lucendo AJ. Systematic review with meta-analysis: the incidence and prevalence of eosinophilic oesophagitis in children and adults in population-based studies. Aliment Pharmacol Ther. 2016;43(1):3-15.

3 Dellon ES, Hirano I. Epidemiology and natural history of eosinophilic esophagitis. Gastroenterology. 2018;154:319-332.e3.

4 Warners MJ, de Rooij W, van Rhijn BD, Verheij J, Bruggink AH, Smout AJPM, et al. Incidence of eosinophilic esophagitis in the Netherlands continues to rise: 20 -year results from a nationwide pathology database. Neurogastroenterol Motil. 2018;30(1):e13165.

5 Molina-Infante J, Gonzalez-Cordero PL, Ferreira-Nossa HC, Mata-Romero P, Lucendo AJ, Arias A. Rising incidence and prevalence of adult eosinophilic esophagitis in midwestern Spain (2007-2016). United European Gastroenterol J. 2018;6(1):29-37.

6 Miehlke S. Clinical features of eosinophilic esophagitis in children and adults. Best Pract Res Clin Gastroenterol. 2015;29(5):739-48.

7 Shaheen NJ, Mukkada V, Eichinger CS, Schofield H, Todorova L, Falk GW. Natural history of eosinophilic esophagitis: a systematic review of epidemiology and disease course. Dis Esophagus. 2018;31(8):doy015.

8 Schoepfer AM, Safroneeva E, Bussmann C, Kuchen T, Portmann S, Simon HU, et al. Delay in diagnosis of eosinophilic esophagitis increases risk for stricture formation in a timedependent manner. Gastroenterology. 2013; 145(6):1230-6.e1.
9 Warners MJ, Oude Nijhuis RAB, de Wijkerslooth LRH, Smout AJPM, Bredenoord AJ. The natural course of eosinophilic esophagitis and long-term consequences of undiagnosed disease in a large cohort. Am J Gastroenterol. 2018;113(6):836-44.

10 Lucendo AJ, Molina-Infante J, Arias Á, von Arnim U, Bredenoord AJ, Bussmann C, et al. Guidelines on eosinophilic esophagitis: evidence-based statements and recommendations for diagnosis and management in children and adults. United European Gastroenterol J. 2017;5(3):335-58.

11 Chuang MY, Chinnaratha MA, Hancock DG, Woodman R, Wong GR, Cock C, et al. Topi$\mathrm{cal}$ steroid therapy for the treatment of eosinophilic esophagitis (EoE): a systematic review and meta-analysis. Clin Transl Gastroenterol. 2015;6:e82.

12 Sawas T, Dhalla S, Sayyar M, Pasricha PJ, Hernaez R. Systematic review with meta-analysis: pharmacological interventions for eosinophilic oesophagitis. Aliment Pharmacol Ther. 2015;41(9);797-806.

13 Tan ND, Xiao YL, Chen MH. Steroids therapy for eosinophilic esophagitis: systematic review and meta-analysis. J Dig Dis. 2015;16(8): 431-42.

14 Murali AR, Gupta A, Attar BM, Ravi V, Koduru P. Topical steroids in eosinophilic esophagitis: systematic review and meta-analysis of placebo-controlled randomized clinical trials. J Gastroenterol Hepatol. 2016;31(6): 1111-9.
15 Lipka S, Kumar A, Miladinovic B, Richter JE. Systematic review with network meta-analysis: comparative effectiveness of topical steroids vs. PPIs for the treatment of the spectrum of eosinophilic oesophagitis. Aliment Pharmacol Ther. 2016;43(6):663-73.

16 Moher D, Liberati A, Tetzlaff J, Altman DG Preferred reporting items for systematic reviews and meta-analyses: the PRISMA statement. PLoS Med. 2009;6(7):e1000097.

17 Davies HT, Crombie IK, Tavakoli M. When can odds ratios mislead? BMJ, 1998;316 (7136):989-91.

18 Parzen M, Lipsitz S, Ibrahim J, Klar N. An estimate of the odds ratio that always exists. J Comput Graphical Stat. 2002:11(2):420-36.

19 Konikoff MR, Noel RJ, Blanchard C, Kirby C, Jameson SC, Buckmeier BK, et al. A randomized, double-blind, placebo-controlled trial of fluticasone propionate for pediatric eosinophilic esophagitis. Gastroenterology. 2006; 131(5):1381-91.

20 Miehlke S, Hruz P, Vieth M, Bussmann C, von Arnim U, Bajbouj M, et al. A randomised, double-blind trial comparing budesonide formulations and dosages for short-term treatment of eosinophilic oesophagitis. Gut. 2016; 65(3):390-9.

21 Viechtbauer W. Conducting meta-analyses in $\mathrm{R}$ with the metafor package. J Stat Software. 2010;36(3):1-48. .

22 Alexander JA, Jung KW, Arora AS, Enders F, Katzka DA, Kephardt GM, et al. Swallowed fluticasone improves histologic but not symptomatic response of adults with eosinophilic esophagitis. Clin Gastroenterol Hepatol. 2012;10(7):742-749.e1. 
23 Butz BK, Wen T, Gleich GJ, Furuta GT, Spergel J, King E, et al. Efficacy, dose reduction, and resistance to high-dose fluticasone in patients with eosinophilic esophagitis. Gastroenterology. 2014;147(2):324-33.e5.

24 Dellon ES, Katzka DA, Collins MH, Hamdani M, Gupta SK, Hirano I. Budesonide oral suspension improves symptomatic, endoscopic, and histologic parameters compared with placebo in patients with eosinophilic esophagitis. Gastroenterology. 2017;152(4):776-786.e5.

25 Dohil R, Newbury R, Fox L, Bastian J, Aceves $S$. Oral viscous budesonide is effective in children with eosinophilic esophagitis in a randomized, placebo-controlled trial. Gastroenterology. 2010:139(2):418-29.

26 Gupta SK, Vitanza JM, Collins MH. Efficacy and safety of oral budesonide suspension in pediatric patients with eosinophilic esophagi- tis. Clin Gastroenterol Hepatol. 2015;13(1): 66-76.e3.

27 Straumann A, Conus S, Degen L, Felder S, Kummer M, Engel H, et al. Budesonide is effective in adolescent and adult patients with active eosinophilic esophagitis. Gastroenterology. 2010;139(5):1526-37.

28 Lucendo AJ, Miehlke S, Schlag C, Vieth M, von Arnim U, Molina-Infante J, et al. Efficacy of budesonide orodispersible tablets as induction therapy for eosinophilic esophagitis in a randomized placebo-controlled trial. Gastroenterology. 2019;157(1):74-86.e15.

29 Rawla P, Sunkara T, Thandra KC, Gaduputi V. Efficacy and safety of budesonide in the treatment of eosinophilic esophagitis: updated systematic review and meta-analysis of randomized and non-randomized studies. Drugs R D. 2018;18(4):259-69.
30 Dellon ES, Woosley JT, Arrington A, McGee SJ, Covington J, Moist SE, et al. Efficacy of budesonide vs fluticasone for initial treatment of eosinophilic esophagitis in a randomized controlled trial. Gastroenterology. 2019: 157(1):65-73.e5

31 Greuter T, Alexander JA, Straumann A, Katzka DA. Diagnostic and therapeutic long-term management of eosinophilic esophagitis- current concepts and perspectives for steroid use. Clin Transl Gastroenterol. 2018;9(12):e212.

32 Lucendo A, Miehlke S, Vieth M, Schlag C, Biedermann L, Santander C, et al. 951a: budesonide orodispersible tablets are highly effective to maintain clinico-histological remission in adult patients with eosinophilic esophagitis: results from the 48-weeks, double-blind, placebo-controlled, pivotal eos-2 trial. Gastroenterology. 2019;156(6):S-1509. 